\title{
Adjective to Verb Zero Derivation in English and Macedonian: Reconsidering the Importance of Cognition in Understanding This Word Formation Process
}

\author{
Marjana Vaneva \\ School of Foreign Languages, University American College Skopje, Skopje, R. Macedonia
}

\begin{abstract}
Zero derivation is a word formation process when the lexemes before and after the process, most often, when talking about clear or genuine types of zero-derivation, share the same form, display similar, expanded meaning, but belong to different lexical categories or subcategories - a characteristic conditioned by adding a zero affix to the first lexeme. Of the several types of zero derivation and the directions of this process that can be distinguished, for this paper the change from adjective to verb lexical category has been chosen to be analysed, by using the cognitive approach. The source, adjectival lexeme is zero derived in the target, verbal element and, when compared and contrasted, both lexemes are formally identical, in analytic languages, like English, but with inflectional modifications in synthetic languages, like Macedonian, displaying a lexical category change and semantic expansion. The aim of the paper is to show that cognition indeed helps in understanding this process in both English and Macedonian. The corpus consists of lexemes taken from reliable English and Macedonian dictionaries, while the elements undergo morphological and semantic analysis. The findings are applicable in any linguistic research which upgrades itself on the nature of the process in these languages.
\end{abstract}

Index Terms — zero derivation, cognition, adjective, verb, English, Macedonian

\section{INTRODUCTION}

Adjectives are parts of speech that describe the noun, while verbs name actions, but the process of zero derivation, which by definition means deriving a new lexeme that belongs to a new lexical (sub) category, with the same form, and with a similar, expanded meaning, makes the lexemes close to each other by connecting them cognitively. Namely, like in every kind of learning, so in this, the cognitive approach is very successful and productive, when on the basis of the meaning of the source word, we conceive the new lexeme. Most, if not all, cognitive linguists agree with Lakoff and Johnson (1980), who say that metaphor is the basic element in our categorization of the world and in the thinking processes. Therefore, metaphor is used as a tool for semantic expansion of the word, when from one domain, the meaning of one lexeme is mapped into another domain. In that way, even the most distant and superficially nonconnectible meanings are connected.

People learn by finding similarities between the new words and the prototype of the given category, and this leads to the understanding that the word meaning is analysed on the basis of its similarity with the prototype. According to Rosch (1977)'s research, all semantic variants of one lexeme are connected with the prototype through closer and more distant links by using metaphor, while the participants in the conversation act understand the abstract concepts by using their physical experience.

In English, Bauer (1983) is only one of the many authors who talks about zero derivation and lists some zero derived forms from adjective to verb, such as: better, dirty, empty, faint, open, right, total (p. 226).

This transfer from one to another category is explained with a zero morph, whose existence is claimed by some linguists when they try to explain the functional difference between homophones and these new formations. The explanation is that when there is no obvious change in the word form there is an affix that marks that change. For instance, empty does not have an obvious affix but it has a zero morph, which comes at the end of the word and the result is empty $+\boldsymbol{\emptyset}$, thus marking the word as a verb. It is needless to say that the zero morph is a controversial issue, because it is accepted in inflectional cases when paralleling the other forms in a paradigm requires an affix.

According to Saeed (1997), the linguistic knowledge is part of the general cognition, and the cognitive linguists emphasise the difference between formal and functional approach towards the language (p. 299). The first, formal approach is often connected with the understanding that the knowledge of linguistic structures and rules forms an autonomous model, independent of the other mental processes of attention, memory and thinking. For the other, functional approach, distinguishing linguistic levels harms our language conceptions, because syntax can never be independent of semantics and pragmatics. 
Hurford and Heasley (1983) maintain that when analyzing zero derivation not one, but three processes should be considered: morphological (when the form of the word changes, by adding a prefix or suffix), syntactic (when the part of speech changes) and semantic (when new meaning is derived) (p. 206).

But, athough Quirk, Greenbaum, Leech and Svartvik (1985) for this process use the name conversion instead of zero derivation, they firmly claim that it is a derivation process, when a new word class is derived without adding an affix (p. 2558). This absolutely goes in line with what Bauer (1983) says, that is, the change in form class happens without any corresponding change of form (p. 32). Katamba (1994) is one more author who takes absolutely the same stand and maintains that the word-form remains the same, but it realizes a different lexical item (p. 70).

In addition to this, Bauer and Valera (2005) in their book Approaches to Conversion/Zero Derivation have collected and presented the opinions of different linguists about the process of zero derivation, thereby saying that there is change in the word class without adding derivational affixes, while addition or omission of inflectional suffixes is allowed.

In Macedonian, Kiril Koneski (1987) talks about zero derivation of verbs from adjectives and he also maintains that the basis of this process is the motivational link between the words that belong to different lexical categories, having the source word on one side, and the derivative as a result of the process on the other side (p. 51-60). This same author, (Kiril Koneski 1995), is among the first in the study of the Macedonian language who talks about the zero affix, explaining that a word formational zero suffix and an inflectional suffix are added to the word formational basis, so that, at the end of the process, a new lexeme is formed as a result of zero derivation (p. 19).

The continuation of this paper studies the process of zero derivation from adjective to verb in both languages, English and Macedonian, by explaining and emphasizing the role of cognition for understanding the process and deriving new lexemes, while at the hearer this results in learning new lexemes due to the reliance on that person's cognitive ability.

\section{Adjective to Verb Zero Derivation in EnGLish}

As the process implies, the feature that the adjective has and with which it modifies the noun, now is being transferred to the verb and denotes the action.

In English, the formula for this direction is the following:

L1 Adj. (= natural class) $+\varnothing \rightarrow$ L2 V. (= zero derived lexeme)

In continuation, we will analyse verbs zero derived from adjectives (although the number of these verbs is smaller than that of the verbs zero derived from nouns):

1. The first group includes intransitive verbs that mean the subject receives the feature or the quality contained in the adjective, which is realized by performing the action:

dry $\rightarrow$ dry: dry hair $\rightarrow$ The paint dries.

mature $\rightarrow$ mature: a mature woman $\rightarrow$ She matured into a woman.

plump $\rightarrow$ plump: The berries were plump and sweet. $\rightarrow$ Stew the dried fruits gently until they plump up.

In the case with dry, whose natural class is adjectival and describes the hair as $\underline{d r y}$, on the other side, the verb dry means performing the action of drying, more precisely, to become dry, and thus the sentence on the right is translated as Бојата се суии. The adjective contains a certain feature, characteristic or quality with which it modifies the noun, and by the adjective transfer into a verbal lexeme, the noun that is in subject position performs the action of spreading or transferring the feature contained in the adjective. In the other examples, from mature as adjective when it means $\underline{\text { speла }}$,

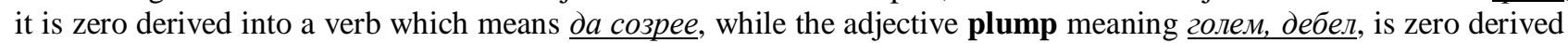
in a verb meaning заоблува, зголемува.

2. The verbs from the second group are transitive and their semantic description explains that, from the adjective that contains the characteristic of the noun, a verb is derived which shows that when the subject does the action, the feature that the adjective gives is transferred to the object which, on the other hand, receives and takes the action on itself. As a matter of fact, the verb means to spread or to transfer to the object the characteristic that the adjective gives:

calm $\rightarrow$ calm: His voice was calm. $\rightarrow$ I calmed him down.

blunt $\rightarrow$ blunt: a blunt knife $\rightarrow$ You should blunt the axe.

open $\rightarrow$ open: The door was wide open. $\rightarrow$ She opened the door.

In the last example, if the adjective open means отворена, then the derived verb means to perform the action of opening, to make the object open, to open something, the same as from the adjective calm - cmuper, the action means to calm the object, and from blunt - $\underline{\text { man }}$, the action means making the object blunt. In our case, the object of this connotation is axe and the cognitive transfer tells us that when the speaker zero derives a verb from an adjective, they want to say the axe to become blunt.

This kind of metaphorical interpretation and cognitive approach towards the lexical transfer from one part of speech into another is the only way to find semantic similarity between the two formally identical lexemes that are used in different grammatical contexts. This method shows that when analyzing the relations and finding similarities and differences between the words it is necessary to take into account all the meanings that the lexeme has and which appear in the speaker's mind. They are significant for explaining the semantic transfer and for making it happen on the path from the source to the target, because by using metaphorisation the speaker connects the basic, prototypical meaning with the less basic, and yet, logical, and cognitively valid meaning. 
As for the inflectional suffixes on the right side of the example, they are allowed and, what is more, essential for reaching grammatical agreement between the verb and the other elements of the sentence - a feature that mirrors the new function of the zero derived lexeme. Thus, from the unchanged adjectival form on the left, the suffixes for tense, person, aspect, and voice are added to the zero derived verb, when we want to agree the verbal form, which in fact illustrates the behaviour of the derived element, with the other sentence parts.

The following shows the scheme for this kind of zero derivation:

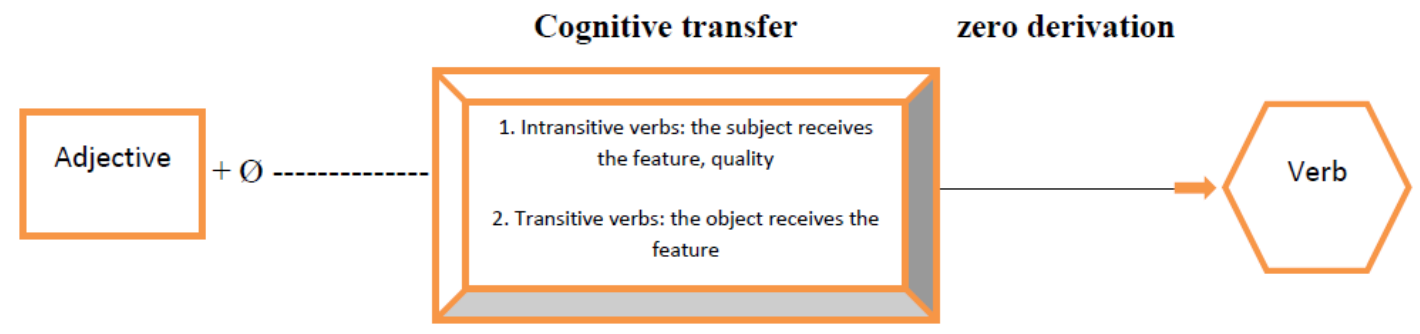

Figure 1. Zero derivation from adjective to verb in English

\section{Adjective to Verb Zero Derivation in Macedonian}

In this group, the adjective and the verb are connected by the process of zero derivation when the adjectival form is basic and the verb is zero derived from it, in which way the person's or the object's feature and characteristic are transferred to the verb and thus mark the action as specified. The following formula shows this kind of zero derivation:

L1 Adj. (=MB+ØWFS) $\rightarrow$ L2 V. (=MB+ØWFS+IS-u) ${ }^{1}$

1. Here, the verb means to make the object receive the feature marked with the adjective and all the following examples illustrate this kind of zero derivation:

чист $\rightarrow$ чист-и: чист случај - Жената чисти секој ден.

богат $\rightarrow$ богат-и: богат сосед $\rightarrow$ Соседот се богати од ден на ден.

полн $\rightarrow$ полн-и: полн автомобил $\rightarrow$ ја полни чантата со книги

In the last example, the adjective полн characterizes the noun автомобил as such in which something is put, and accordingly the verb полни is understood to mean to put something in the object, that is, in the noun so that it becomes full. The explanation for the other examples is also similar. Namely, the car is full because somebody has put something in it, so starting with this kind of cognitive reasoning we can conclude that the zero derived verb means to put something in the object so that it becomes such as described by the source adjective.

In each process of verb derivation, complex formal-semantic processes happen, thus from the basic, starting adjective the result is a zero derived imperfective verb: бел $\rightarrow$ бели, which in this case means to become white, to whiten the cloth. This interpretation is accompanied by Veleva's explanation (1993), where she claims that colours have proved to be productive word formation bases for creating new words that will enrich the language expression (p. 21). According to her, with their presence in the Macedonian language we show respect for the tradition of the folk creativity, and also the stylistic-expressive function of the colour is shown, the purpose of which is to emphasise the expressiveness and the picturesqueness, as well as to determine the reflexive tone of the expression.

Actually, colours are being discussed in this kind of zero derivation because they are convenient bases for deriving verbs, in cases when, by using the adjective, verbs with resultative meaning are created, and the following are some of them: бели, жолти, зелени, модри, црвени, црни.

Let us see how these lexemes behave in the examples in continuation:

бел $\rightarrow$ бел-и: бел sид $\rightarrow$ го бели платното

црвен $\rightarrow$ црвен-и: црвен корал $\rightarrow$ Јаболкото се црвени на врвот на дрвото.

црн $\rightarrow$ црн-и: ирн човек $\rightarrow$ Секој месеи си ја црни косата.

In the first example, the explanation of the semantic transfer and of the metaphorical link of the adjective - starting, and the verb - resulting, zero derived lexeme is the following: if the noun, that is the object is white, then by using that colour we perform the action the noun, or the object to become white, or to fade away, to lose its basic colour. The semantic link between the source and the target lexeme is the same in the other examples: when from a feature contained in the adjective, the transfer is to an action, which means to make the object such as the characteristic of the first lexeme is.

Of course, not always does this mean colour change; namely, the subject does not have to apply certain colour to the object so the adjective that names the colour zero derives into a verb which, by itself, denotes the colouring.

Applying the colour coincided with the first and the third of the previously given examples, when the cloth is being coloured white and the hair black, but in the second example the developing of red colour, that is, the red colour of the

\footnotetext{
${ }^{1}$ The symbols that are used in this formula, and some of them in the following formula in this paper, designate the following elements:

L1 = lexeme 1, L2 = lexeme 2, Adj. = adjective, V. = verb, MB = motivational basis, $\varnothing=$ zero, WFS = word formation suffix, IS = inflectional suffix.
} 
apple is natural, comes as a result of the process of getting ripe, and in no way does it mean that somebody has colored the apple on the tree red.

2. On one side of the example, instead of an adjective-noun combination, we can have a nominal structure consisting of a copula and an adjective, where the adjective still modifies the noun by transferring to it the feature built in itself, while the verbal derivative means the subject to display the feature characteristic of the carrier of the feature denoted with the adjective. This can be illustrated with the formula $x+$ copula + adjective, when after performing zero derivation, the result is $x+a$ zero derived verb from an adjective, where $x$ takes the feature denoted with the basic adjective and now performs the action whose product will be creating noun that has the feature of the source adjectival lexeme. This can be sufficiently illustrated with the following example:

Патот е крив. $\rightarrow$ Патот криви.

This kind of zero derivation from adjective to verb by making cognitive interpretation is very productive in reflexive verbs, which are not realized as transitive and thus mean the subject to become such, to receive the feature of the adjective contained in the basis:

бајат $\rightarrow$ бајат-и: бајат леб $\rightarrow$ Млекото се бајати на топло.

весел $\rightarrow$ весел-и: весел гостин $\rightarrow$ Гостинот се весели.

дебел $\rightarrow$ дебел-и: дебел човек $\rightarrow$ Од ден на ден таа сѐ повеќе се дебели.

In these examples, the metaphorisation is easy, natural and expected; there is very little abstraction, as is the case with the whole group, because the meaning transfer from the lexeme in the source group into the target group is understandable. Actually, the speaker connects the concrete and the abstract in the lexemes with the same form very easily and inconspicuously. Thus, when we say that the bread is баjaт, we refer to the fact that it is stale, and inedible, while the verb which can be both reflexive and irreflexive (in our sentence on the right is used reflexively), implies that the subject, that is, the milk will go sour by itself, will become stale, and won't be edible.

The speaker will give similar interpretation of the other examples of adjective to verb zero derivation. The adjective can take articles, as the derivative can be marked by tense, number and person.

\section{Cognitive transfer zero derivation}

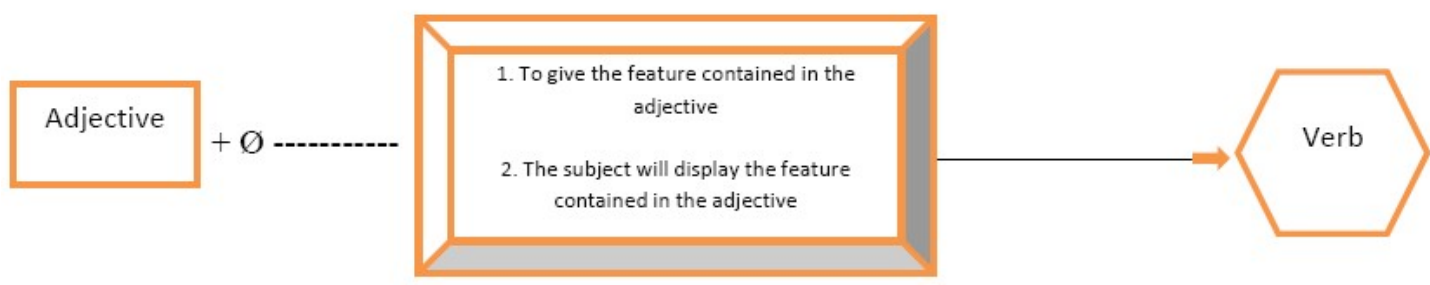

Figure 2. Zero derivation from adjective to verb in Macedonian

\section{CONCLUSION}

Having chosen English and Macedonian to be analysed for the purpose of this paper, I certainly anticipated differences in this process manifestation, which is due to the fact that these language structures belong to different language families, and thus first display formal, morphological discrepancies, but then also mutual syntactic characteristics and semantic similarities.

Bearing in mind the synthetic nature of Macedonian and the analytic character of English, we embrace the linguistic situation that is offered to us: that in English the process of zero derivation from adjective to verb is clear, genuine, prototypical, meaning that there are no inflectional interventions in the form of the lexemes before and after the process, and therefore there is absolute overlapping between the source and the target lexeme. What immensely helps us in deciding which of the two formally identical lexical elements is the first one, that is, what the right direction of the process is, is the concept of natural class evidenced by the use of reliable dictionaries, which document the proper use of the words. It is in phrasal or sentential context when the lexemes take inflections that are characteristic of their part of speech, thus realizing themselves and displaying their new function.

In Macedonian, the concept of natural class is verified with the data obtained from The Dictionary of the Macedonian Language with Serbo-Croatian Interpretations (Речник на македонскиот јазик со српскохрватски толкувања), which is used as the most reliable source that gives evidence about the natural class to which the Macedonian lexemes (primarily) belong. By taking the lexeme in its natural class (an adjective) and following the semantic expansion, through cognition we come to another lexeme (verb) that, in Macedonian, due to this language's inflectional characteristic, has an inflectionally modified form, semantically expanded representation, and belongs to a completely different lexical category.

In English, the lexemes undergo smaller changes, because English has far fewer inflections and therefore does not change the form that easily, meaning that both lexical participants in the process - the adjective and the verb - have 
absolutely the same form (from inflectional point of view), but the meaning is slightly changed (as the new lexeme's function requires), in accordance with the requirements of the different lexical categories to which the lexemes belong.

\section{REFERENCES}

[1] Велева, С. (1993). Боите како продуктивни зборообразувачки основи. Прв научен собир на млади македонисти, 15-22.

[2] Bauer, L. (1983). English Word-formation. Cambridge: Cambridge University Press.

[3] Bauer, L. \& S. Valera. (2005). Approaches to Conversion / Zero Derivation. Münster: Waxmann Publishing Co.

[4] Hurford, J. R. \& B. Heasley. (1983). Semantics: a coursebook. Cambridge: Cambridge University Press.

[5] Katamba, F. (1994). English Words. London and New York: Routledge.

[6] Конески, Б. (ред.). (1994). Речник на македонскиот јазик со српскохрватски толкувања (том: 1, 2, 3). Скопје: Детска радост.

[7] Конески, К. (1987). Од проблематиката на зборообразувањето на глаголите во македонскиот јазик. Предавања на XIX Семинар за македонски јазик, литература и култура, 51-61.

[8] Конески, К. (1995). Зборообразувањето во современиот македонски јазик. Скопје: Бона.

[9] Lakoff, G. \& M. Johnson. (1980). Metaphors We Live By. (2nd edn.). Chicago: University of Chicago Press.

[10] Pearsall, J. \& P. Hans. (eds.). (1998). The New Oxford Dictionary of English (1st edn.). Oxford: Oxford University Press.

[11] Quirk, R., S. Greenbaum, G. Leech \& J. Svartvik. (1985). A Comprehensive Grammar of the English Language. London and New York: Longman.

[12] Rosch, E. (1977). Human categorization. In N. Warren (ed.), Advances in cross-cultural psychology (vol. 1). London: Academic Press, 1-72.

[13] Saeed, J. I. (1997). Semantics. Oxford: Blackwell Publishers Ltd.

Marjana Vaneva is an Assistant Professor and Dean of the School of Foreign Languages at the University American College Skopje, Republic of Macedonia. As a graduated teacher of English with an MA (2005) and PhD (2009) degrees in Linguistics from the "Ss Cyril and Methodius University" in Skopje, she mainly teaches English grammar subjects to English language students at undergraduate and postgraduate level. Her research interests are in the domain of applied linguistics, cognitive linguistics, semantics, contrastive analysis, language testing, and English language teaching. She has published on zero derivation, negative prefixes, homonymy and polysemy, cognition in teaching vocabulary, and also on teaching second/foreign language grammar. 